\title{
Testing for regime-switching CAPM on Zagreb Stock Exchange
}

\author{
Tihana Škrinjarić ${ }^{1, *}$ \\ ${ }^{1}$ Faculty of Economics and Business, University of Zagreb \\ Trg J. F. Kennedyja 6, 10000 Zagreb, Croatia \\ E-mail: 〈tskrinjaric@efzg.hr〉
}

\begin{abstract}
The standard Capital Asset Pricing Model assumes that a linear relationship exists between the risk (beta) and the expected excess return of a stock. However, empirical findings have shown over the years that this relationship varies over time. Stock markets undergo phases of greater and smaller volatility in which beta varies accordingly (undergoes different regimes). Given that the Croatian capital market is still insufficiently investigated, the aim of this paper is to explore the possibility of a nonlinear relationship between the stock risk and return. Linear and Markov-switching models (Hamilton 1989) are examined on the Zagreb Stock Exchange based on monthly data on 21 stocks, ranging from January 2005 to December 2013. In that way, investors can use the results based on the best model when making decisions about buying stocks. Since this is one of the first papers on regime-switching on the Croatian capital market, it will hopefully contribute to the existing literature on investing.
\end{abstract}

Key words: regime-switching, Zagreb Stock Exchange, CAPM, time-varying beta

Received: September 2, 2014; accepted: November 22, 2014; available online: December 30, 2014

\section{Introduction}

Modern portfolio theory has derived many useful concepts of stock (as well as other securities) evaluation, in which quantifying stock risk is important for portfolio construction, as well as in financial management in general. The Capital Asset Pricing Model (CAPM) [42, 37] is probably one of the most famous evaluation models in finance theory. The model is used to estimate the market risk of an individual stock or a well-diversified portfolio. In that way, an investor can measure the sensitivity of an asset's excess return to changes in market's excess return. It is a linear model [2], which means that the excess stock return is linearly related to the non-diversifiable risk [13:164]. It has been empirically tested numerous times on both developed markets, and on markets in development. Despite its many flaws (see, for example, [19]), it is still tested

${ }^{*}$ Corresponding author. 
today, not only in its original form, but also by taking into account different modifications (see $[17,18]$ ). On the Croatian capital market, it has been tested several times only in its original form with conclusions that deny its power of a systematic risk prediction.

Over the past 30 years many authors have shown that a stock's average return and risk fluctuate over time and the original CAPM model cannot explain stock return anomalies. Furthermore, it has been determined that beta varies over time (see $[14,10,17,18,27,15,29]$, etc.). Fruk and Huljak [20] concluded that investors should be careful when using betas as a risk measure on the Zagreb Stock Exchange, while Perković [40] and Džaja and Aljinović [13] demonstrated that beta cannot be trusted as a risk measure when making investment decisions on the Croatian stock market. The relationship between risk and return is not always linear, and the original CAPM as a linear model fails to explain the movements in stock return and risk. There are even econometric consequences: "When betas vary over time, standard OLS inference is misspecified and cannot be used to assess the fit of a conditional CAPM. Moreover, when betas vary over time and are correlated with time-varying market risk premia, OLS alphas and betas provide inconsistent estimates of conditional alphas and conditional betas, respectively." [5:1].

This problem was solved by introducing regime switching models which incorporate changes in the observed variables by modeling not only the mean equation, but also the probabilities of staying in different states of the world. The most popular regime switching model is the one Hamilton [23] developed. It is broadly used for detecting bull and bear markets ${ }^{\dagger}$ and in modeling an unobserved discrete-time, discrete-state Markov process [30]. This paper follows the Hamilton (1989) [23] and the popular Huang [26] approach of modeling stock returns on the Zagreb Stock Exchange. In that way, it can finally be seen whether the CAPM model modified by regime switching behavior can explain the relationship between stock return and risk on Croatian capital market. There are only several papers in the Croatia dealing with the CAPM and switching regime methodology. Thus, we are hoping to contribute to the scarce literature on that topic. The paper is organized as follows. Section 2 deals with previous theoretical and empirical research regarding the original and regime switching CAPM. The methodology used in this paper is described in the Section 3, while empirical investigation and results are given in Section 4. Section 5 concludes the paper.

\footnotetext{
${ }^{\dagger}$ The aforementioned research has shown that when the prices are rising, volatility is low, thus the low volatility regime responds to the bull markets. On the contrary, when the prices are dropping on the stock market, volatility becomes higher and this phase is identified as the bear market.
} 


\section{Short survey of previous literature}

By analyzing previous foreign and domestic research it can be concluded that regime switching methodology is widely used in finance practice in foreign literature, while domestic research lacks CAPM analyses and even more a regime switching approach. Since many papers referring to the linear CAPM model are mentioned very often in the literature, only those applying regime switching models will be reviewed.

Huang [26] is one of the researchers whose approach is very popular. He applied the first order Markov chain in order to model switching behavior of beta in the CAPM model on the Microsoft Corporation monthly stock returns for the period from April 1986 to December 1993. Assoe [7] found strong evidence of two regime switching in nine emerging market returns for monthly data on stock market price indices from December 1975 to December 1997. Korkmaz, Çevik and Gürkan [31] dealt with 23 emerging markets and examined the period from January 1995 to April 2009 in order to compare the linear to the Markov switching model. The results of their investigation have shown that risk can be time varying, depending on the regime prevailing on the market. Galagadera and Shami [21] used daily data on 30 securities in the DJI index for the period from 2 January 1990 to 23 May 1996. They classified stocks by probability of being in a low or a high risk state and concluded that some stock returns produce strong switching behavior. Abdymomunov and Morley [1] analyzed stock returns on value weighted decile portfolios of all stocks listed on the New York Stock Exchange, AMEX and NASDAQ for the period from July 1963 to December 2010. Using a two-state Markov-switching process, they found evidence of time variation betas, which rejects the original unconditional CAPM model. They concluded that the regime-switching model explains returns much better. A list of some other applications of Markov switching approaches in finance is given in [49] and [22].

By observing the domestic literature, only several papers on the CAPM or switching regime can be found. Fruk and Huljak [20] tested the original CAPM model for 17 stocks on the Zagreb Stock Exchange for the period from September 1998 to August 2003. They concluded that despite a positive relationship between returns and beta, investors should be careful when making decisions about investing. Perković [40] conducted regression estimation of the model for 15 stocks for a more recent period (July 2005 to December 2009) in order to test whether beta can be used as a suitable risk measure. Based on the estimation results, he concluded that beta is not an adequate risk measure on the Croatian capital market. Finally, Džaja and Aljinović [13] tested the model for nine Central and South-East European markets, including Croatia. Their sample was the newest, ranging from January 2006 to December 2010. For all of the countries, they found that bigger returns do not mean a bigger beta, thus 
they confirmed the previous results that beta is not a valid measure of risk on the observed markets. Markov chain and regime switching methodology is also rarely present in the domestic research. Based on monthly data on CROBEX from January 2001 to December 2009 Kunovac [34] identified two regimes on the Zagreb Stock Exchange. He compared the results from forming a Markowitz model based on three stocks when the regimes are taken under consideration and when they are not. His results have shown that forming portfolios based on switching regimes result in better performance compared to others. Some other regime switching works combine Markov switching with GARCH ${ }^{\ddagger}$ methodology (see [6] or [49]), while others combine Markov Chain methodology with Markowitz portfolio optimization [45], and some apply a nonparametric approach to Markov Chain modeling [44]. As can be seen, a general deficiency of regime switching methodology is present in the domestic research.

\section{Methodology}

W. Sharpe [42] and J. Lintner [37] independently developed the Capital Asset Pricing Model, which is used to explain the excess return of an asset. It is assumed that all investors seek the efficient portfolio in a Markowitz [38] framework, and combine risky assets in combination with a risk-free asset. An important aspect of the models is a risk measure, named beta, which measures sensitivity of an asset to changes in market's excess return. Formally, beta of the $i$-th stock is calculated as:

$$
\beta_{i}=\frac{\operatorname{cov}\left(r_{i t}, r_{m t}\right)}{\sigma_{m}^{2}}
$$

where $r_{i t}$ represents excess return ${ }^{\S}$ on the $i$-th stock (asset) in moment $t$, $i \in\{1,2, \ldots, I\}, r_{m t}$ excess stock market return in moment $t$ and $\sigma_{m}^{2}$ is the variance of market return. Jensen [28] introduced a time-series regression test [19], in which the excess return should be explained completely by the risk premium, and thus Jensen's alpha should be zero for each asset. Empirical evaluation of the CAPM model is given by:

$$
r_{i t}=\alpha_{i}+\beta_{i} r_{m t}+\varepsilon_{i t}, i \in\{1,2, \ldots, I\},
$$

\footnotetext{
${ }^{\ddagger}$ Generalized Autoregressive Conditional Heteroskedasticity.

$\S$ Excess return is calculated as $r_{i t}=R_{i t}-r_{f t}$, where $R_{i t}$ represents the return on the $i$-th stock in moment $t$ and $r_{f t}$ represents a risk-free return in moment $t$. The excess market return is calculated as $r_{m t}=R_{m t}-r_{f t}$, where $R_{m t}$ represents a stock market return.
} 
where $\alpha_{i}$ represents the $i$-th stock's Jensen's alpha, which measures the abnormal stock return, $\beta_{i}$ is the mentioned risk measure of the $i$-th stock and $\varepsilon_{i t}$ is the error term, which is assumed to be iid $\mathrm{N}\left(0, \sigma^{2}\right)$. $I$ is the number of stocks. The model given in equation (2) will be marked as $M_{1}$.

Since many authors have shown that the CAPM failed to explain stock return and risk (in addition to the mentioned works, see [8, 36, 35, 5, 9], etc.), many studies employing the regime switching CAPM have been emerging in the last two decades. The first ones focused on developed markets, and successively emerging markets that started to be examined. Here, we follow Turner et al. [48], Abdymomunov and Morley [1] and especially Huang [26] and their approach to modeling the Markov regime-switching CAPM. It is assumed that the model is specified for two different states or regimes. One state is a low, and the other is a high volatility regime, which corresponds to bull and bear markets. A Markov process is a stochastic process $\left\{X_{t}\right\}$ if it has the property that, given the value of $X_{t}$, the values of $X_{s}, s>t$, do not depend on the values $X_{r}, r<t: P\left(X_{s} \mid X_{r}, r \leq t\right)=P\left(X_{s} \mid X_{t}\right), s>t$ [47]. Two different Markov regime switching models will be examined. The first one assumes that only beta varies over time. Thus, equation (2) becomes:

$$
r_{i t}=\alpha_{i}+\beta_{i S_{t}} r_{m t}+\varepsilon_{S_{t}}, i \in\{1,2, \ldots, I\},
$$

where we can see that beta is characterized with switching behavior as well as the error term. Henceforward, the model in (3) will be marked as $M_{2} . S_{t}$ is the unobservable state variable, which evolves according to the first order Markov switching process defined as:

$$
\begin{aligned}
& P\left[S_{t}=1 \mid S_{t-1}=1\right]=p=p_{11}, P\left[S_{t}=2 \mid S_{t-1}=1\right]=1-p=p_{21}, \\
& P\left[S_{t}=2 \mid S_{t-1}=2\right]=q=p_{22}, P\left[S_{t}=1 \mid S_{t-1}=2\right]=1-q=p_{12},
\end{aligned}
$$

where $P\left[S_{t}=j \mid S_{t-1}=i\right]$ gives the probability that state $i$ is followed by state $j$ [26:575]. $p$ and $q$ are fixed transition probabilities of being in a low or a high volatility regime. In a matrix notation, we can define the probability transition matrix as:

$$
\boldsymbol{P}=\left[\begin{array}{ll}
p_{11} & p_{12} \\
p_{21} & p_{22}
\end{array}\right],
$$

and since we are dealing with probabilities, it holds that $0 \leq p_{j i} \leq 1 \forall i, \forall j$ and $\sum_{j=1}^{2} p_{j i}=1, \forall i$. Thus, it follows that: 


$$
\beta_{i S_{t}}=\left\{\begin{array}{l}
\beta_{i}^{1}, \text { if } S_{t}=1 \\
\beta_{i}^{2}, \text { if } S_{t}=2
\end{array}, \quad \sigma_{S_{t}}\left\{\begin{array}{l}
\sigma_{1}, \text { if } S_{t}=1 \\
\sigma_{2}, \text { if } S_{t}=2
\end{array} .\right.\right.
$$

The error term is characterized as iid $\mathrm{N}\left(0, \sigma_{S_{t}}^{2}\right)^{* *}$. The second regime switching model, which will be examined, is the following:

$$
r_{i t}=\alpha_{i S_{t}}+\beta_{i S_{t}} r_{m t}+\varepsilon_{S_{t}}, i \in\{1,2, \ldots, I\},
$$

where both beta and Jensen's alpha vary due to the state variable $S_{t}$, so an addition to (5) is made as:

$$
\alpha_{i S_{t}}=\left\{\begin{array}{l}
\alpha_{i}^{1}, \text { if } S_{t}=1 \\
\alpha_{i}^{2}, \text { if } S_{t}=2
\end{array} .\right.
$$

Expected duration of the $j$-th state can be calculated as [24]: $d_{1}=\frac{1}{1-p}$ and $d_{2}=\frac{1}{1-q}$. Details on maximum likelihood estimation of parameters in switching regime model $\boldsymbol{\theta}_{i}=\left(\alpha_{i}^{1}, \alpha_{i}^{2}, \beta_{i}^{1}, \beta_{i}^{2}, \sigma_{1}, \sigma_{2}, p_{11}, p_{22}\right)$ by using numerical optimization or the EM algorithm and on filtered and smoothed probabilities are given in $[23,24,50,33,26]$.

In order to determine which model is most suitable for assets on the Croatian capital market (is it justifiable to apply the Markov switching model), a test for switching parameters should be conducted. However, standard likelihood ratio tests of the null hypothesis of no breaks cannot be performed, due to the fact that values $p_{11}$ and $p_{22}$ are not identified under the null hypothesis (nuisance parameters). When there are unidentified parameters under the null hypothesis, the likelihood function is flat with respect to them, and the optimum is not unique. This problem is solved by conducting a supremum statistics test, of which Davies [11, 12], Hansen [25], Andrews [3], Andrews and Ploberger [4] are most popular (for more discussion and tests, see [46]). This research applies the sup-Wald test of Andrews, where the $L M$ test statistic $L M_{T}($ п) is calculated as given in [3:837], as well as asymptotic critical values. Three tests will be applied for each stock: two regime switching models ((3) and (6)) will be compared to the linear model and to each other. In that way, the best relationship between the stock and market return can be estimated.

${ }^{* *}$ Usually, when analyzing financial data the assumption of a Gaussian distribution of error terms is often replaced by a Student's distribution. 


\section{Empirical analysis}

For the purpose of empirical analysis, monthly data on most liquid stocks on the Zagreb Stock Exchange was collected from ZSE [51]. The data consists of price data on 21 stocks and CROBEX index for the period from January 2005 to December 2013. Since excess returns needed to be calculated, a risk-free interest rate on Treasury Bills was obtained from the Ministry of Finance [39]. The analysis was conducted by using TSM 4.42 software. Stock returns were calculated as continuously compounded returns:

$$
R_{i t}=\ln \left(\frac{P_{i t}}{P_{i t-1}}\right)
$$

where $R_{i t}$ represents the return on the $i$-th stock ${ }^{\dagger \dagger}$ in moment $t, P_{i t}$ the price of the $i$-th stock in moment $t$ and $\ln$ stands for the natural logarithm. Each return was adjusted for the risk-free rate in order to obtain the excess return as: $r_{i t}=R_{i t}-r_{f t}$, where $r_{f t}$ represents the risk-free return in moment $t$.

Unit root tests $\$$ were performed for each stock and CROBEX excess return, which resulted in the conclusion that all excess returns are stationary. Then, an OLS estimation of the original CAPM model was conducted $\$$. Out of 21 regressions, 13 Jensen's alphas were not statistically significant on the usual levels of significance. In 10 regressions, $R^{2}$ was less than 0.2 , with the highest one being 0.43 . Overall, this means that the original CAPM model has a very weak explanatory power, as concluded by previous research. Thus, we move on to the regime switching models. Andrews [3] $L M$ test was performed in order to determine which model is the most adequate one. The regime switching models were estimated by Broyden, Fletcher, Goldfarb and Shanno numerical quasiNewton optimization algorithm ${ }^{* * *}$. The results are given in Table 1, where test $L M_{T}$ (п) statistics is given and the $p$-values are in parentheses. The first column of each stock, labeled $\mathrm{M}_{1} \mid \mathrm{M}_{2}$, compares model $\mathrm{M}_{1}$ to $\mathrm{M}_{2}$, etc. As can be seen, the

\footnotetext{
¡A And CROBEX index as well.

$¥ \mathrm{ADF}$ unit root test was performed in levels, with constant and trend and only constant as deterministic components. For each stock, except KOEI and KORF, test results on a $1 \%$ significance level indicated to reject the null hypothesis. For two mentioned stocks, the null can be rejected on a $5 \%$ level. Additionally, a PP test was performed on two mentioned stocks, which confirmed that their returns are a stationary process. Full results of the mentioned tests are omitted due to the lack of space but are available upon request.

$\$$ Again, the results are omitted, but are available upon request.

${ }^{* * *}$ Default initial values of $p=q=0.5$ were used.
} 
results of the first test prefer the beta switching regime model on a $1 \%$ significance level, except for stocks HUPZ, PODR and BLJE (5\%) and KOEI (10\%). When comparing model $\mathrm{M}_{3}$ (alpha and beta switching regime) to $\mathrm{M}_{1}$, the test prefers model $\mathrm{M}_{3}$ for each stock on a $1 \%$ significance level, except HUPZ $(5 \%)$ and PODR (model $\mathrm{M}_{1}$ is better). Since models $\mathrm{M}_{2}$ and $\mathrm{M}_{3}$ are preferable to $\mathrm{M}_{1}$ for most of the stocks, the final $L M$ test was performed in order to choose the best model for each stock. By looking at the third column of each stock, it can be seen that model $\mathrm{M}_{3}$ is preferred to $\mathrm{M}_{2}$ for each stock on a $1 \%$ significance level, except ADPL, KORF (5\%), PODR (10\%), ARNT and HUPZ $\left(\mathrm{M}_{2}\right.$ is preferable). Clearly, there exists evidence on regime switching behavior in alphas and betas (which means that OLS provides inconsistent estimates).

\begin{tabular}{|c|c|c|c|c|c|c|c|c|c|c|c|}
\hline Stock & $\mathrm{M}_{1} \mid \mathrm{M}_{2}$ & $\mathrm{M}_{1} \mid \mathrm{M}_{3}$ & $\mathrm{M}_{2} \mid \mathrm{M}_{3}$ & Stock & $\mathrm{M}_{1} \mid \mathrm{M}_{2}$ & $\mathrm{M}_{1} \mid \mathrm{M}_{3}$ & $\mathrm{M}_{2} \mid \mathrm{M}_{3}$ & Stock & $\mathrm{M}_{1} \mid \mathrm{M}_{2}$ & $\mathrm{M}_{1} \mid \mathrm{M}_{3}$ & $\mathrm{M}_{2} \mid \mathrm{M}_{3}$ \\
\hline \multirow{2}{*}{ ADPL } & 25.969 & 13.737 & 6.225 & & 10.782 & 7.432 & 459.591 & \multirow{2}{*}{ LKPC } & 58.370 & 25.231 & 33.312 \\
\hline & $(0.000)$ & $(0.003)$ & $(0.044)$ & & $(0.000)$ & $(0.000)$ & $(0.000)$ & & $(0.000)$ & $(0.000)$ & $(0.000)$ \\
\hline \multirow{2}{*}{ ADRS } & & & 50.560 & & 7.371 & 9.206 & 1.018 & \multirow{2}{*}{ LKRI } & 50.533 & 53.835 & 45.509 \\
\hline & $(0.000)$ & $(0.000)$ & $(0.000)$ & & $(0.025)$ & $(0.027)$ & $(0.601)$ & & $(0.000)$ & $(0.000)$ & $(0.000)$ \\
\hline \multirow{2}{*}{ ARNT } & & 102.444 & 0.480 & & 98.439 & 351.609 & 22.779 & \multirow{2}{*}{ PODR } & 6.962 & 6.162 & 5.0233 \\
\hline & $(0.000)$ & $(0.000)$ & $(0.787)$ & & $(0.000)$ & $(0.000)$ & $(0.000)$ & & $(0.031)$ & $(0.104)$ & $(0.081)$ \\
\hline \multirow{2}{*}{ ATPL } & 33.611 & 34.893 & 27.725 & & 5.398 & 68.634 & 14.76 & \multirow{2}{*}{ PTKM } & 23.309 & 40.363 & 35.066 \\
\hline & $(0.000)$ & $(0.000)$ & $(0.000)$ & & $(0.067)$ & $(0.000)$ & $(0.000)$ & & $(0.000)$ & $(0.000)$ & $(0.000)$ \\
\hline \multirow{2}{*}{ BLJE } & 6.113 & 14.882 & 14.176 & & 42.947 & 14.872 & 8.358 & \multirow{2}{*}{ ULPL } & 11.272 & 15.041 & 8.526 \\
\hline & $(0.047)$ & $(0.002)$ & $(0.001)$ & & $(0.000)$ & $(0.002)$ & $(0.015)$ & & $(0.000)$ & $(0.002)$ & $(0.014)$ \\
\hline \multirow{2}{*}{ DDJH } & 13.476 & 21.726 & 18.939 & & 28.409 & 29.1667 & 714.691 & \multirow{2}{*}{ VDKT } & 64.953 & 124.035 & 12.373 \\
\hline & $(0.001)$ & $(0.000)$ & $(0.000)$ & & $(0.000)$ & $(0.000)$ & $(0.001)$ & & $(0.000)$ & $(0.000)$ & $(0.002)$ \\
\hline \multirow{2}{*}{ DLKV } & 31.642 & 31.801 & 31.723 & & 29.9111 & 29.695 & 29.671 & \multirow{2}{*}{ ZABA } & 38.343 & 92.464 & 87.699 \\
\hline & $(0.000)$ & $(0.000)$ & $(0.000)$ & & $(0.000)$ & $(0.000)$ & $(0.000)$ & & $(0.000)$ & $(0.000)$ & $(0.000)$ \\
\hline
\end{tabular}

Table 1: Results of Andrews Structural Change LM test

Since test results were ambiguous, log likelihood maxima were compared, as well as Akaike, Schwarz and Hannan-Quinn information criteria, tools commonly used for model selection. The Table is given in the appendix. Based on the results from that table and Table 1, an appropriate model was chosen for each stock. The results of estimation are given in Table 2 . 


\begin{tabular}{|c|c|c|c|c|c|c|c|c|}
\hline Stock & $\hat{\alpha}_{\text {low }}$ & $\hat{\alpha}_{\text {high }}$ & $\hat{\beta}_{\text {low }}$ & $\hat{\beta}_{\text {high }}$ & $\hat{\sigma}_{\text {low }}$ & $\hat{\sigma}_{\text {high }}$ & $\hat{p}_{11}$ & $\hat{p}_{22}$ \\
\hline $\mathrm{ADPL}$ & \multicolumn{2}{|c|}{$-0.022(0.02)$} & $\begin{array}{c}0.250 \\
(0.285)\end{array}$ & $\begin{array}{c}0.671 \\
(0.232)\end{array}$ & 0.029 & 0.134 & 0.777 & 0.835 \\
\hline ADRS & $\begin{array}{c}-0.037 \\
(0.007)^{* * *}\end{array}$ & & & $\begin{array}{c}0.854 \\
(0.063)^{* * *}\end{array}$ & 0.022 & 0.067 & 0.544 & 0.829 \\
\hline ARNT & \multicolumn{2}{|c|}{$0.002(0.012)$} & $\begin{array}{c}0.569 \\
(0.347)\end{array}$ & $\begin{array}{c}0.627 \\
(0.197)^{* * *}\end{array}$ & 0.053 & 0.095 & 0.927 & 0.988 \\
\hline ATPL & $\begin{array}{c}-0.040 \\
(0.014)^{* * *}\end{array}$ & $\begin{array}{c}0.040 \\
(0.028)\end{array}$ & $\begin{array}{c}0.587 \\
(0.162)^{* * *}\end{array}$ & $\begin{array}{c}1.148 \\
(0.290)^{* * *}\end{array}$ & 0.058 & 0.144 & 0.887 & 0.777 \\
\hline BLJE & $\begin{array}{c}-0.034 \\
(0.010)^{* * *}\end{array}$ & & $\begin{array}{c}0.652 \\
(0.105)^{* * *}\end{array}$ & $\begin{array}{c}0.180 \\
(0.394)\end{array}$ & 0.059 & 0.384 & 0.911 & 0.825 \\
\hline DDJH & $\begin{array}{c}-0.039 \\
(0.001)^{* * *}\end{array}$ & & $\begin{array}{c}0.015 \\
(0.011)\end{array}$ & $\begin{array}{c}0.858 \\
(0.088)^{* * *}\end{array}$ & 0.004 & 0.315 & 0.801 & 0.969 \\
\hline DLKV & $\begin{array}{l}-0.014 \\
(0.013) \\
\end{array}$ & $\begin{array}{l}-0.067 \\
(0.039)^{*}\end{array}$ & $\begin{array}{c}0.890 \\
(0.340)^{* *}\end{array}$ & $\begin{array}{c}0.614 \\
(0.160)^{* * *}\end{array}$ & 0.072 & 0.156 & 0.969 & 0.952 \\
\hline ERNT & & & $\begin{array}{c}0.614 \\
(0.160)^{* * *}\end{array}$ & $\begin{array}{c}0.890 \\
(0.340)^{* *} \\
\end{array}$ & 0.049 & 0.071 & 0.726 & 0.900 \\
\hline HUPZ & \multicolumn{2}{|c|}{$-0.025(0.334)$} & $\begin{array}{c}0.315 \\
(9.763) \\
\end{array}$ & $\begin{array}{c}-0.433 \\
(133.844)\end{array}$ & 0.062 & 0.198 & 0.990 & 0.965 \\
\hline INGR & $\begin{array}{c}0.028 \\
(0.156) \\
\end{array}$ & $\begin{array}{c}-0.079 \\
(0.013)^{* * *}\end{array}$ & $\begin{array}{c}0.406 \\
(1.623) \\
\end{array}$ & $\begin{array}{c}0.555 \\
(0.117)^{* * *}\end{array}$ & 0.170 & 0.360 & 0.985 & 0.991 \\
\hline KOEI & & & & & 0.067 & 0.139 & 0.986 & 0.946 \\
\hline $\mathrm{KORF}$ & & & $\begin{array}{r}0.9 \\
(0.39\end{array}$ & $\begin{array}{r}0.6 \\
(0.5\end{array}$ & 0.067 & 0.126 & 0.870 & 0.773 \\
\hline KRAS & & $\begin{array}{c}-0.079 \\
(0.021)^{* * *}\end{array}$ & $\begin{array}{r}0.35 \\
(0.23\end{array}$ & $\begin{array}{c}0.239 \\
(0.070)^{* * *}\end{array}$ & 0.053 & 0.084 & 0.986 & 0.949 \\
\hline LEDO & $\begin{array}{l}-0.006 \\
(0.009)\end{array}$ & & $\begin{array}{c}0.640 \\
(0.204)^{* * *}\end{array}$ & $\begin{array}{c}0.902 \\
(0.260)^{* * *}\end{array}$ & 0.058 & 0.167 & 0.968 & 0.961 \\
\hline LKPC & & $\begin{array}{c}-0.036 \\
(0.005)^{* * *}\end{array}$ & $\begin{array}{c}0.001 \\
(0.068)\end{array}$ & $\begin{array}{c}0.898 \\
(0.209)^{* * *}\end{array}$ & 0.018 & 0.136 & 0.800 & 0.882 \\
\hline LKRI & $\begin{array}{c}-0.020 \\
(0.009)^{* *}\end{array}$ & $\begin{array}{c}-0.007 \\
(0.025) \\
\end{array}$ & $\begin{array}{c}0.061 \\
(0.234) \\
\end{array}$ & $\begin{array}{c}0.979 \\
(0.321)^{* * *}\end{array}$ & 0.030 & 0.129 & 0.796 & 0.934 \\
\hline PODR & \multicolumn{2}{|c|}{$-0.015(0.007)^{* *}$} & $\begin{array}{c}0.676 \\
(0.130)^{* * *} \\
\end{array}$ & $\begin{array}{c}0.442 \\
(0.090)^{* * *} \\
\end{array}$ & 0.042 & 0.069 & 0.979 & 0.972 \\
\hline PTKM & $\begin{array}{c}0.062 \\
(0.006)^{* * *}\end{array}$ & & $\begin{array}{c}-4.089 \\
(0.359)^{* * *}\end{array}$ & $\begin{array}{c}0.615 \\
(0.224)^{* * *}\end{array}$ & 0.011 & 0.108 & 0.520 & 0.980 \\
\hline ULPL & $\begin{array}{c}-0.038 \\
(0.013)^{* * *}\end{array}$ & $\begin{array}{l}-0.026 \\
(0.014)^{*}\end{array}$ & $\begin{array}{c}-0.472 \\
(0.253)^{*}\end{array}$ & $\begin{array}{c}0.633 \\
(0.204)^{* * *}\end{array}$ & 0.054 & 0.162 & 0.986 & 0.985 \\
\hline VDKT & $\begin{array}{l}-0.021 \\
(0.020)\end{array}$ & $\begin{array}{c}0.015 \\
(0.026)\end{array}$ & $\begin{array}{l}1.176 \\
(0.887)\end{array}$ & $\begin{array}{c}1.159 \\
(0.324)^{* * *}\end{array}$ & 0.057 & 0.164 & 0.785 & 0.920 \\
\hline ZABA & $\begin{array}{c}-0.020 \\
(0.007)^{* * *}\end{array}$ & $\begin{array}{c}-2.653 \\
(0.243)^{* * *}\end{array}$ & $\begin{array}{c}0.770 \\
(0.082)^{* * *}\end{array}$ & $\begin{array}{l}-11.184 \\
(5.358)^{* *}\end{array}$ & 0.077 & 0.294 & 0.900 & 0.100 \\
\hline
\end{tabular}

Table 2: Markow-switching CAPM results 
Note: $\mathrm{M}_{2}$ model was chosen for ADPL, ARNT, HUPZ and PODR. For every other stock, model $\mathrm{M}_{3}$ was chosen. The first four columns for each stock report estimated coefficients along with standard errors. Low and high stand for low and high volatility on the stock market, respectfully. $\hat{\sigma}_{\text {low }}$ and $\hat{\sigma}_{\text {high }}$ report error standard deviations, $\hat{\boldsymbol{p}}_{11} / \hat{\boldsymbol{p}}_{22}$ reports probability that a state of a low/high volatility regime will occur after a low/high volatility regime. ${ }^{* * *},{ }^{* *}$ and ${ }^{*}$ indicate significance on a $1 \%, 5 \%$ and $10 \%$ level, respectfully. Each model was estimated with an assumption of Student's t-distribution, because the Jarque Bera test rejected the hypothesis of normal distribution of error terms on usual levels of statistical significance. Furthermore, Ljung Box test was performed on the residuals and squared residuals and on usual levels of statistical significance there is no problem of autocorrelation or heteroskedasticity up to lag 12 .

Examining Jensen's alpha, 14 stocks exhibit a statistically significant alpha, only two of which are positive, which indicates that only KOEI and PTKM generate abnormal returns in a low volatility regime. Looking at betas, only 2 stocks have insignificant betas in any market regime; 12 have higher betas in a high volatility regime, which means that when turbulences are present on the market, these stocks become more risky. Other 9 become less risky and 2 reverse their movements compared to the market. According to the CAPM theory, stocks with negative betas in bear markets and positive betas in bull markets move against the market movements. Their returns are negatively correlated to the market return and investors can reduce the losses by incorporating these stocks into portfolios when the market is bullish, and remove them from the portfolio when the market is bearish. Comparing estimated error standard deviations, a high volatility regime produces risk which is on average 7 times greater than a low volatility regime ${ }^{i t \dagger}$. Each regime is on average strongly persistent, due to the high transition probabilities for each regime. The duration of a low volatility regime ranges from 4.5 to 100 months, and from 1 to 111 months for a high volatility regime. Furthermore, the number of months needed for switching from a low to a high regime ranges from 2.1 to 112.1 months, and 3.1 to 101 months vice versa probabilities are higher than 0.8 ; and on average a high volatility transition probability is equal to 0.88 , while for the low it is equal to 0.86 . This persistency

\footnotetext{
${ }^{i \dagger}$ Beta is a measure of systematic risk of an individual stock, and the std. deviations are measures of the volatility (risk) of the market as a whole. For more details, see Korkmaz et al (2010), ShuHwa and Ho (2008) for more details.

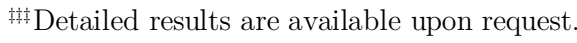


is in accordance with other studies of CEE markets (see, for example, [32] or [41]).

Finally, an example of estimated smoothed probability for a high volatility regime of LEDO stock was graphically constructed and compared to the movements on CROBEX return (see Figure 1). As can be seen, the chosen regime switching model is adequate. When the market return exhibits a higher volatility, the transition probability $p_{22}$ is high, thus indicating that the market is in a high volatility regime. The results correspond to the matching time span part in [34].

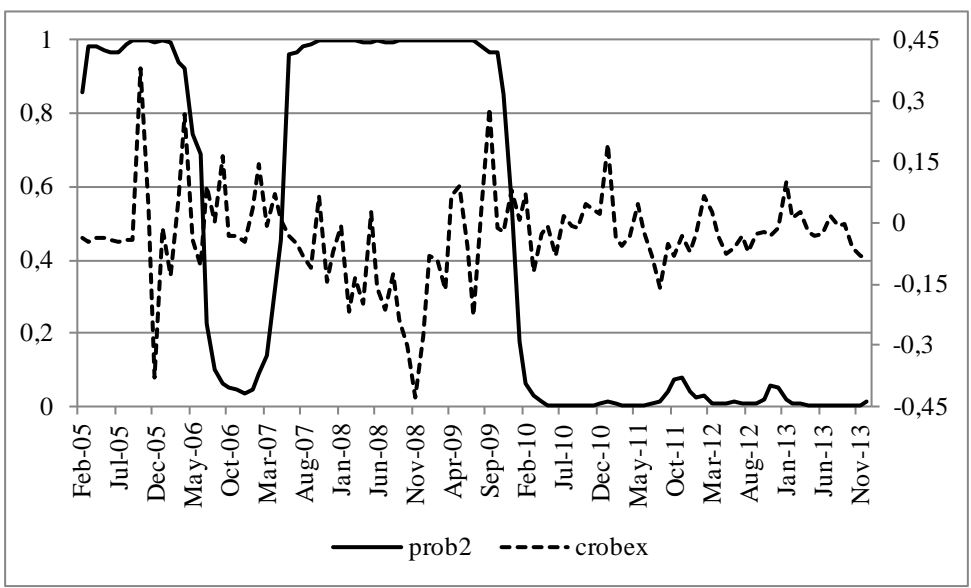

Figure 1: Smoothed probability in a high volatility regime for LEDO stock

\section{Discussion and conclusion}

Despite its many flaws the original CAPM model plays an important role in finance and Modern Portfolio Theory. The model's validity has been questioned on the Croatian capital market. Thus, this study has attempted to reconsider the model by incorporating regime switching methodology. Regime switching models have been proven to capture the nonlinearities between stock return and risk. The results of the empirical investigation point out that beta, and even Jensen's alpha, vary over time. There exists a statistically significant difference between betas in different market regimes. In that way, the results from the linear CAPM model when investors consider it can be misleading. It is advisable to apply regime switching methodology when trying to predict stock returns. Some shortcomings of this study were the relative short time span of the sample, because there is a lack of liquidity on the Croatian capital market. Only 
the excess market return was observed as an explanatory variable in the model, but there are modifications to the original model (adding book-to-market ratio, size effect, etc.; see [16]). Therefore, more research has to be conducted in this area. Moreover, based on the results from the most adequate model, investment strategies can be formed in order to achieve more reliable results than when not taking into account such nonlinearities and anomalies. Since this is one of the first studies on regime switching on the Croatian capital market, it will hopefully contribute to the existing literature on investing.

\section{References}

[1] Abdymomunov, A. and Morley, J. (2011). Time variation of CAPM betas across market volatility regimes. Applied Financial Economics, 21, 146-1478.

[2] Aljinović, Z., Marasović, B. and Šego, B. (2011). Financijsko modeliranje, drugo izmijenjeno i dopunjeno izdanje, (Financial modelling, second modified and updated edition), Sveučilište u Splitu, Ekonomski fakultet (University of Split, Faculty of Economics).

[3] Andrews, D. W. K. (1993). Tests for parameter instability and structural change with unknown change point. Econometrica, 61, 821-856.

[4] Andrews, D. W. K. and Ploberger, W. (1994). Optimal tests when a nuisance parameter is present only under the alternative. Econometrica, 62(6), 1383-1414.

[5] Ang, A. and Chen, J. (2005). CAPM over the long run: 1926-2001. NBER Working Paper Series, National Bureau of Economic Research.

[6] Arnerić, J. and Erjavec, N. (2010). Regime switching modelling of structural changes caused by financial crisis. Proceedings of the 5th International Conference an Enterprise Odyssey: From Crisis to Prosperity - Challenges for Government and Business / Galetić, L., Spremić, M., Ivanov, M. (eds). - Zagreb: Faculty of Economics and Business, 79-80.

[7] Assoe, K. G. (1998). Regime-switching in emerging stock market returns. Multinational Finance Journal, 2, 101-132.

[8] Blume, M. E. (1971). On the assessment of risk. Journal of Finance, 26, 1-10.

[9] Brooks, R., Faff, R. and Lee, J. (1994). Beta stability and portfolio formation. Pacific-Basin Finance Journal, 2, 463-479.

[10] Chen, S. N. (1982). An examination of risk-return relationship in bull and bear markets using time-varying security betas. Journal of Financial and Quantitative Analysis, 17, 265-286.

[11] Davies, R. B. (1977). Hypothesis testing when a nuisance parameter is present only under the alternative. Biometrika, 64, 247-254.

[12] Davies, R. B. (1987). Hypothesis testing when a nuisance parameter is present only under the alternative. Biometrika, 74, 33-43. 
[13] Džaja, J. and Aljinović, Z. (2013). Testing CAPM model on the emerging markets of the Central and Southeastern Europe. Croatian Operational Research Review (CRORR), Vol. 4, 164-175.

[14] Fabozzi, F. and Francis, J. C. (1977). Stability tests for alphas and betas over bull and bear market conditions. Journal of Finance, 32, 1093-1099.

[15] Faff, R. W.F. and Brooks, R. D. (1997). Further evidence on the relationship between beta stability and the length of estimation period. Advances in Investment Analysis and Portfolio Management, 4, 97-113.

[16] Fama E. and French, K. (1993). Common risk factor in the returns on stock and bonds. Journal of Financial Economics, 33, 3-56.

[17] Fama E., French, K. (1996). Multifactor explanations of asset pricing anomalies. Journal of Finance, Vol. 51, No. 1, 55-84.

[18] Fama, E. and French, K. (1992). The cross-section of expected stock return. Journal of Finance, 47, 427-465.

[19] Fama, E. and French, K. (2004). The capital asset pricing model: Theory and evidence. Journal of Economic Perspectives, Vol. 18, No. 3, 25-46.

[20] Fruk, M. and Huljak, I. (2004). Testiranje Sharpe-Linterova modela na Zagrebačkoj burzi (Testing out the Sharpe-Lintner model on the Zagreb Stock Exchange), Financijska teorija i praksa (Financial Theory and Practice), 28 (1), 77-91.

[21] Galagadera, D. U. A. and Shami, R. (2003). Association between Markov regimeswitching market volatility and beta risk: Evidence from Dow Jones industrial securities. Working Paper, Monash University Australia, ISSN 1440-771X.

[22] Guidolin, M. (2012). Markov switching models in empirical science. Working Paper No. 415, IGIER - Univeristá Bocconi.

[23] Hamilton, J. D. (1989). A new approach to the economic analysis of nonstationary time series and the business cycle. Econometrica, 57(2), 357-384.

[24] Hamilton, J. D. (1994). Time Series Analysis. New Jersey: Princeton University Press.

[25] Hansen, B. E. (1992). The likelihood ratio test under nonstandard conditions: Testing the Markov switching model of GNP. Journal of Applied Econometrics, 7, S61-S82

[26] Huang, H-C. (2000). Tests of regimes-switching CAPM. Applied Financial Economics, 10, 573-578.

[27] Jagannathan, R. and Wang, Z. (1996). The conditional CAPM and the cross-section of expected returns. The Journal of Finance, 51(1), 3-53.

[28] Jensen, M. C. (1968). The performance of mutual funds in the period 1945-1964. Journal of Finance, 23, 389-416.

[29] Kim, C. J., Morley, J. C. and Nelson, C. R. (2004). Is there a positive relationship between stock market volatility and the equity premium? Journal of Money, Credit, and Banking, 36, 339-60. 
[30] Kim, C-J. (1994). Dynamic linear models with Markov-switching. Journal of Econometrics, 60, 1-22.

[31] Korkmaz, T., Çevik, E. I. and Gürkan, S. (2010). Testing of the international capital asset pricing model with Markov switching model in emerging markets. Investment Management and Financial Innovations, Vol. 7, No. 1, 37-49.

[32] Kouretas, G. and Syllignakis, M. (2012) Switching volatility in emerging stock markets and financial liberalization: Evidence from the new EU Member Countries. Central European Journal of Economic Modelling and Econometrics, Vol. 4, Issue 2, 65-93.

[33] Kuan, C-M. (2002). Lecture on the Markov switching model. Institute of Economics, Academica Sinica.

[34] Kunovac, D. (2011). Assymetric correlation on the Croatian equity market. Financial Theory and Practice, 35(1), 1-24.

[35] Lettau, M. and Ludvigson, S. (2001). Resurrecting the (C)CAPM: A cross-sectional test when risk premia are time-varying. Journal of Political Economy, 109, 1238-87.

[36] Levy, R. A. (1971). On the short-term stationarity of beta coefficients. Financial Analysts Journal, 27, 55-62.

[37] Lintner, J. (1965). The valuation of risk assets and the selection of risky investments in stock portfolios and capital budgets. Review of Economics and Statistics, 47 (1), $13-37$.

[38] Markowitz, H. (1952). Portfolio selection. The Journal of Finance, Vol. 7, No. 1, 7791.

[39] Ministry of Finance (2014). http://www.mfin.hr [Accessed on 16 August 2014].

[40] Perković, A. (2011). Research of beta as adequate risk measure - is beta still alive? Croatian Operational Research Review (CRORR), Vol. 2, 102-111.

[41] Schröder, M. (ed.) (2000). The New Capital Markets in Central and Eastern Europe. Final Report, Centre for European Economic Research.

[42] Sharpe, W. F. (1964). Capital asset prices: A theory of market equilibrium under conditions of risk. Journal of Finance, 19 (3), 425-442.

[43] Shu-Hwa, C. and Ho, T. (2008) Risk-return tradeoffs in emerging markets: Evidence from Markov-switching model. Working paper, Shih Hsin University.

[44] Škrinjarić, T. and Kojić, V. (2014). Modeliranje prinosa dionica na Zagrebačkoj burzi pomoću Markovljevih lanaca (Modelling stock returns on Zagreb Stock Exchange by using Markov chains), Ekonomski pregled: mjesečnik Hrvatskog društva ekonomista Zagreb (Economic review: Monthly Croatian association of economists Zagreb), 65, 3, 207-221.

[45] Škrinjarić, T. and Šostarić, N. (2014). Komplementarnost metodologije Markovljevih lanaca i Markowitzeva modela optimizacije portfelja (The complementarity of Markov chains methodology and Markowitz portfolio optimization model), Ekonomska misao i praksa: časopis Sveučilišta u Dubrovniku (Economic Thought and Practice: periodical of the University of Dubrovnik), 1, 353-370. 
[46] Smith, A. (2012). Markov breaks in regression models. Journal of Time Series Econometrics, Vol. 4, No. 1, 1928-1941.

[47] Tsay, R. S. (2004). Analysis of Financial Time Series, 2nd edition. New Jersey: Wiley-Interscience.

[48] Turner, C. M., Startz, R. and Nelson, C. R. (1989). A Markov model of heteroskedasticity, risk, and learning in stock market. Journal of Financial Economics, 25, 3-22.

[49] Visković, J., Arnerić, J. and Rozga, A. (2014). Volatility switching between two regimes. International Journal of Social, Human Science and Engineering, Vol. 8, No. 3, 62-66.

[50] Wang, P. (2009). Financial Econometrics, Second edition. Routledge, New York.

[51] Zagreb Stock Exchange (2014). http://www.zse.hr [Accessed on 16 August 2014].

\section{APPENDIX}

\begin{tabular}{|c|c|c|c|c|c|c|c|c|}
\hline \multirow{2}{*}{ Stock } & \multicolumn{2}{|c|}{ Log Likelihood } & \multicolumn{2}{|c|}{ AIC } & \multicolumn{2}{c|}{ SIC } & \multicolumn{2}{c|}{ HQ } \\
\cline { 2 - 9 } & $\mathrm{M}_{2}$ & $\mathrm{M}_{3}$ & $\mathrm{M}_{2}$ & $\mathrm{M}_{3}$ & $\mathrm{M}_{2}$ & $\mathrm{M}_{3}$ & $\mathrm{M}_{2}$ & $\mathrm{M}_{3}$ \\
\hline ADPL & 112.221 & 116.219 & 103.221 & 106.219 & 91.193 & 92.855 & 98.345 & 100.802 \\
ADRS & 157.333 & 160.209 & 148.333 & 150.209 & 136.305 & 136.845 & 143.457 & 144.792 \\
ARNT & 74.883 & 77.851 & 65.883 & 67.851 & 53.855 & 54.487 & 61.007 & 62.433 \\
ATPL & 101.429 & 104.219 & 92.429 & 94.219 & 80.402 & 80.855 & 87.553 & 88.801 \\
BLJE & 88.441 & 88.542 & 79.441 & 78.542 & 67.414 & 65.178 & 74.565 & 73.124 \\
DDJH & 76.827 & 78.050 & 67.827 & 68.050 & 55.799 & 54.686 & 62.951 & 62.633 \\
DLKV & 90.388 & 91.758 & 81.388 & 81.758 & 69.361 & 68.394 & 76.512 & 76.341 \\
ERNT & 138.289 & 138.613 & 129.289 & 128.613 & 117.249 & 115.249 & 123.195 & 124.413 \\
HUPZ & 130.949 & 132.399 & 121.949 & 122.399 & 109.921 & 109.035 & 117.073 & 116.981 \\
INGR & 47.383 & 47.416 & 38.383 & 37.416 & 26.355 & 24.051 & 33.507 & 31.998 \\
KOEI & 133.051 & 132.793 & 124.051 & 122.793 & 112.023 & 109.429 & 119.175 & 117.375 \\
KORF & 104.114 & 103.888 & 95.114 & 93.888 & 83.086 & 80.524 & 90.238 & 88.470 \\
KRAS & 144.131 & 144.523 & 135.131 & 134.523 & 123.104 & 121.159 & 130.255 & 129.105 \\
LEDO & 96.463 & 96.956 & 87.463 & 86.956 & 75.435 & 73.592 & 82.587 & 81.539 \\
LKPC & 115.993 & 117.673 & 106.993 & 107.673 & 94.966 & 94.309 & 102.117 & 102.255 \\
LKRI & 90.003 & 90.270 & 81.003 & 80.270 & 68.975 & 66.906 & 76.127 & 74.853 \\
PODR & 155.862 & 157.466 & 146.862 & 147.466 & 134.834 & 134.102 & 141.862 & 142.048 \\
PTKM & 97.609 & 100.503 & 88.609 & 90.503 & 76.581 & 77.139 & 83.733 & 85.0855 \\
ULPL & 112.495 & 112.497 & 103.495 & 102.497 & 91.468 & 89.133 & 98.620 & 97.0792 \\
VDKT & 60.746 & 61.479 & 51.746 & 51.479 & 39.719 & 38.115 & 46.871 & 46.061 \\
ZABA & 113.785 & 112.919 & 104.785 & 112.919 & 92.757 & 89.555 & 99.909 & 97.501 \\
\hline
\end{tabular}

Table 3. Criteria for model selection 